\title{
Borderland, from Archive to Gallery: Working on James Cowan's Papers
}

\author{
ARIANA TIKAO
}

\begin{abstract}
In 2012 the Alexander Turnbull Library purchased a large collection of writer/historian James Cowan's (1870-1943) working papers, adding to an already substantial holding. This descriptive article focuses on the arrangement and description of these papers, and the subsequent curation of the exhibition Borderland: The World of James Cowan, curated by Ariana Tikao. The article discusses the archival principles of provenance and original order in relation to these papers, and also issues surrounding the physical arrangement and the creation of the records. It goes on to delineate the structure of the exhibition, describing key themes of Borderland such as the Ōrākau battle, Cowan's involvement with film, Pākehā Māori, and Cowan's connections with Tikao's own whānau, of Banks Peninsula.
\end{abstract}

As the Māori specialist in the Arrangement and Description team in the Alexander Turnbull Library I am often on the lookout for collections with Māori language or subject matter. Consequently, when I heard the Library was making a new acquisition of papers relating to James Cowan, I indicated an interest in working on them. At first I was drawn to them because of their Māori content, as I knew that Cowan had written about Māori culture and history. Another reason for my interest was that Cowan had interviewed my great-grandfather in the 1920s and had written a book called Maori Folk-tales of the Port Hills as a result of those interviews. I was quietly hoping that this new lot of papers might include material relating to them.

While I was working on the papers, the Library invited proposals for the Turnbull Gallery and I proposed an exhibition to highlight the new collection. There was evidence of a growing interest in Cowan's work, after a period of being out of vogue. This interest was reflected in the work of Chris Hilliard, in his 1997 MA thesis Island Stories: The writing of New Zealand history 1920-1940 and resulting book The Bookmen's Dominion (2006) and also in Greg Wood's 2010 MA thesis Revisiting James Cowan: A Reassessment of The New Zealand Wars (1922-23). I saw that there was some significant content in these new unpublished papers that scholars would be interested in.

The exhibition was called Borderland: The World of James Cowan and was shown in the Turnbull Gallery from February to April 2014. It was this exhibition that sparked the Cowan symposium in February 2014 which gave rise to this Special Issue of the Journal of New Zealand Studies.

\section{Arrangement and description of the papers}

The recently acquisitioned Cowan papers (MS-Group-2097) were purchased by the Turnbull Library from the Art + Object auction house at the end of 2012. Initially, they came to us in ten separate lots that were purchased at auction. ${ }^{1}$ After I had worked on these initial lots (which became the first 14 folders of the collection), our then manuscripts curator, David Colquhoun, approached the auction house to see if they had any more. They did indeed have more-five large banana boxes more, all of which the Library then negotiated to purchase. ${ }^{2} \mathrm{We}$ tried to find out about the provenance of these papers but the auction house would not be very specific. The content of the collection, which was similar to a previous acquisition from Cowan's widow in 1949, suggested that these too came from the Cowan family estate, but we did not receive details from the auction house to verify this. 
The latest papers (both 2012 accessions) consist of research papers, including correspondence, transcripts, drafts, notebooks and newspaper clippings. The correspondence includes a letter from the pioneer film-maker Rudall Hayward, and letters from participants on both sides of the New Zealand Wars, including Heni Pore, Gilbert and and William Mair, and from the Ngāti Maniapoto historian Raureti Te Huia, whose father had fought at Ōrākau. It also includes letters containing whakapapa and waiata, and others from publishers engaging Cowan's services, including the Auckland Star, which wrote suggesting he write a series of articles for Enzed Junior (see Kathryn Parsons' article in this issue). The notebooks include material on the Māori history of Taupō, the Urewera, Kāpiti Island, Horowhenua, Rotorua, Whakatāne and Murupara, and notes on the New Zealand Wars, particularly the Waikato and Taranaki wars.

\section{The provenance of the papers}

Provenance helps us to understand the social and historical context of archival collections. The International Council on Archives website contains the following definition of provenance:

1. The origin or source of something. - 2. Information regarding the origins, custody, and ownership of an item or collection. Provenance is a fundamental principle of archives, referring to the individual, family, or organization that created or received the items in a collection. The principle of provenance or the respect des fonds dictates that records of different origins (provenance) be kept separate to preserve their context. ${ }^{3}$

When thinking about the provenance of the new Cowan papers, my colleagues and I considered whether these papers could be regarded as "further papers" to the Library's earlier Cowan acquisition, or whether they should be regarded as a separate provenance, since their custodial history was uncertain. ${ }^{4}$ The material is very much like the earlier acquisition of Cowan papers but the "chain of custody" of the later papers, showing the connection back to the Cowan family, appeared to have been broken. We therefore decided to keep these papers as a separate group. The records for each group cross-reference each other in the "Other notes" field of the descriptive record, as there is a clear relationship between them. They are both clearly James Cowan's working papers. This is evident in the way he grouped the papers, letters addressed to him, and his many annotations all over the papers.

\section{Original order}

There is often value in how a record or a collection has been grouped or ordered by the collection's creator. We call this "original order." The first lots that we purchased at auction were relatively well-organised, probably having been sorted by the auction house. They came with the information from the auction's catalogue, which I used when describing them. Of the next lot, i.e. the five banana boxes, the first three boxes came with a list that described various bundles, which were given numbers. The last two boxes were not sorted or listed at all. Where there was a number in the list, I recorded this in the "arrangement" field of the record of the descriptive record.

It is clear that Cowan often grouped his papers in a certain way, probably to make it easier for him as he rewrote articles or worked on a particular publication. This is often apparent in his labelling of envelopes or notebooks. Sometimes we dispose of envelopes when sorting collections, but these ones were kept because of the clues they give to Cowan's personal arrangement of his papers. The way we have ordered the collection now is a mix of Cowan's original order and that which was applied by the auction house when they arranged it for sale. 


\title{
Series
}

Archival series are often applied to larger collections, to group records to make it easier for researchers. The original papers had six series attached:

\author{
1 Correspondence \\ 2 Notebooks and other research papers relating mainly to Māori subjects \\ 3 Māori material - Printed papers \\ 4 Plans and drawings \\ 5 Manuscripts \\ 6 Newspaper clippings and periodicals
}

For the new material, I decided on four categories, based on both the content of the new collection, and on the principle of retaining as much of the original order as possible. Often there is a mix of different types of material in the same folder, however, so I had to choose the "best fit" in terms of which series to apply. The series I chose were:

1 Correspondence

2 Research papers

3 Drafts

4 Printed matter

In the end, the new collection was made up of 202 folders and five volumes. In each "volume" there might sometimes be three or four of Cowan's original notebooks. So the collection is quite sizeable.

\section{Physical arrangement}

When we get boxes of papers such as these, we methodically go through them and carefully take items out of their envelopes. We assess the contents of the envelopes and transfer the papers to acid-free folders, sometimes taking out rusty pins or paperclips first. It is quite timeconsuming to process this type of collection. In this instance, this was in part due to the way the papers had been tightly folded in small envelopes for many years, and we needed to be able to open them out to ascertain information about them. This made them difficult to process, and it would also be difficult for researchers to read them. So some items were sent to our conservators to relax the papers (which involves humidifying, or other methods of flattening).

\section{Creating records}

Around this time in the arrangement and description process, we create records on our online database, Tapuhi. The individual records, such as this sample record, are attached to the group record, which is MS-Group-2097. The item record includes a brief description, and is linked to authority headings, which might include: place names, peoples' or organisations' names, dates, iwi/hapū names, subjects (including Māori Subject Headings ${ }^{6}$ ) and other information such as the physical material type, and which languages apply to it. All of these fields in the records, along with keyword searching, become points of access into the collections for a researcher. 


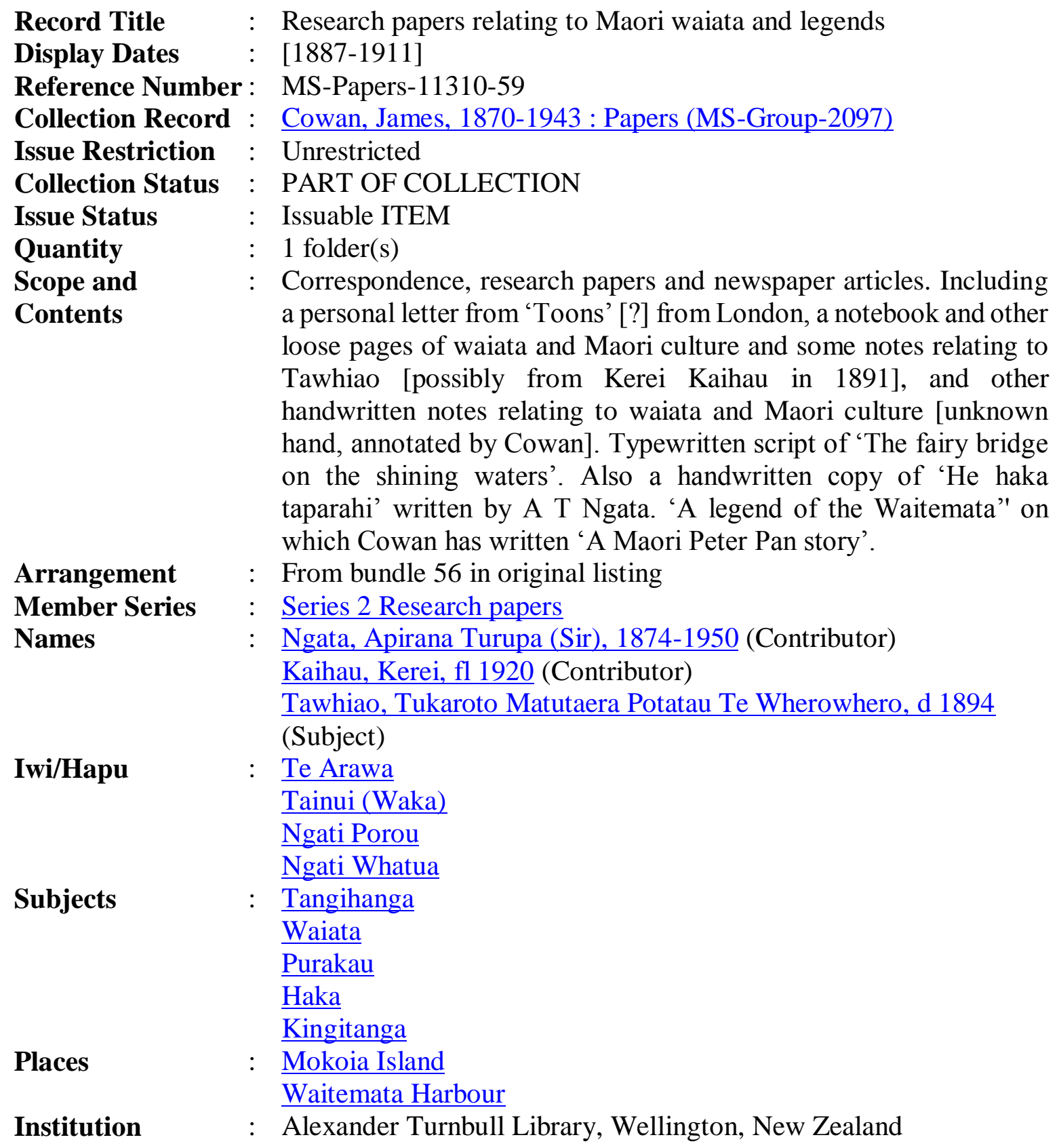

Sample record: MS-Papers-11310-59 


\section{Curating Borderland}

The acquisition coinciding with the $150^{\text {th }}$ anniversary of the Waikato War seemed to be a good opportunity for the library to highlight Cowan and his work, and also gave us an opportunity to acknowledge the importance of the New Zealand Wars. When I was researching for the exhibition, I quickly came to realise how broad Cowan's interests were and how influential his writing has been. This is reflected in the wide range of articles in this special issue of the Journal of New Zealand Studies. It was a daunting task at first, when I thought I would need to represent all of the areas that Cowan covered in his writing. But then my mind was put at ease when Peter Ireland, the Turnbull's gallery and exhibitions specialist, suggested that for the small Turnbull Gallery it was best to be more specific and to focus on the aspects about Cowan that interested me the most. This took me back to my initial reasons for wanting to work on his papers: my interest in Māori history and culture, Cowan's Ōrākau (and wider New Zealand Wars connection), and my whānau connection with Cowan through my great-grandfather.

The exhibition was arranged in five sections. The first, "Beginnings-Tìmatanga," was an introductory section showing how the exhibition came about. It started with a picture I took of a bundle of papers from the Cowan collection when I was working on them.

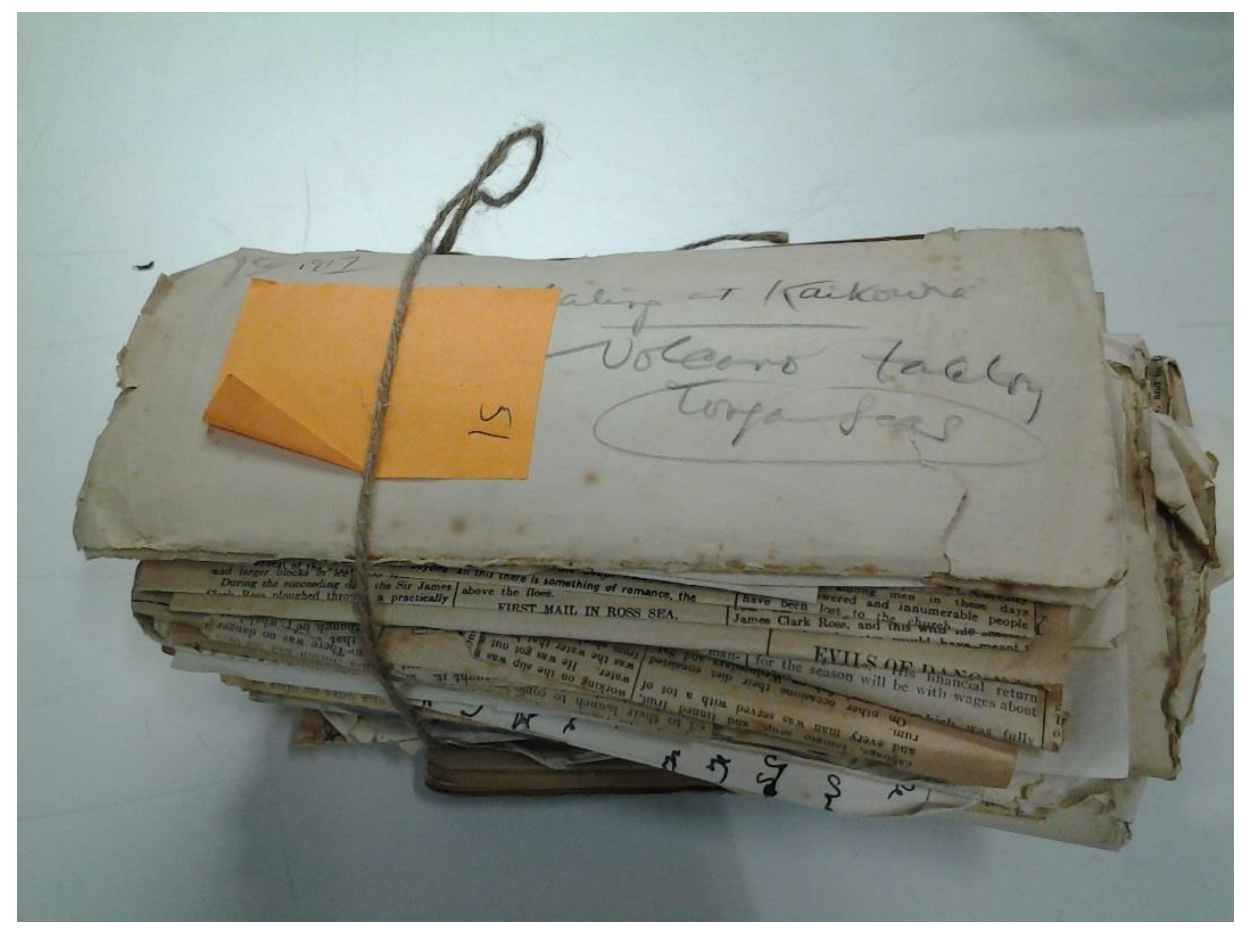

Figure 1. Bundle of papers from recent Cowan papers, MS-Group-2097

Among the items in this section was a small doodle ${ }^{7}$ created by Cowan when he was trying out ideas for a potential book title, which included the term "Borderland." This word leapt out at me while I was working on the papers, and I noted it down as a possible title for the exhibition. "Borderland" was also a nod to Cowan's upbringing near the rohe pōtae border just after the Waikato war, and also referenced the borders he crossed due to the nature of his work and working methods (which included taking interviewees to sites of significance, to relate their stories prompted by the immediacy of the places where events had occurred). 
A further item in this section is the little book Māori Folk-tales of the Port Hills (1923), based on interviews with my great-grandfather Hone [Teone] Taare Tikao. ${ }^{8}$ This book was almost all I knew about Cowan prior to working on his papers, and it points towards my personal connection with Cowan and this material. The other items include photographs of Cowan and his family, and a letter that Eileen Cowan wrote to the journalist Eric Ramsden after her husband's death, in which she says that he didn't write for any particular public, but "because he must." She also talked about Cowan as very shy, adding that the frequent requests that he received to do public talks, always gave him "the horrors."

The second part of the exhibition, "Friends - Ōna hoa," placed Cowan in context. The case material included letters to and from Cowan. One, to his father-in-law Henry Stowell, aka Hare Hongi, discusses a lament that Hongi had sent him relating to his research on the Ngāti Tama leader Te Puoho. Cowan acknowledges the lament's beauty and "poetic lines," but goes on to say he could not make use of it "because it is the taonga of others" (original emphasis). At first glance, Cowan's acknowledgment of the concept of Māori intellectual or cultural property seems today to be quite a modern way of thinking. But since Cowan had grown up in close contact with Waikato Māori, and had married into a Māori family, he was probably well aware of tikanga and Māori thinking surrounding the concept of kaitiakitanga, or guardianship of culturally significant material.

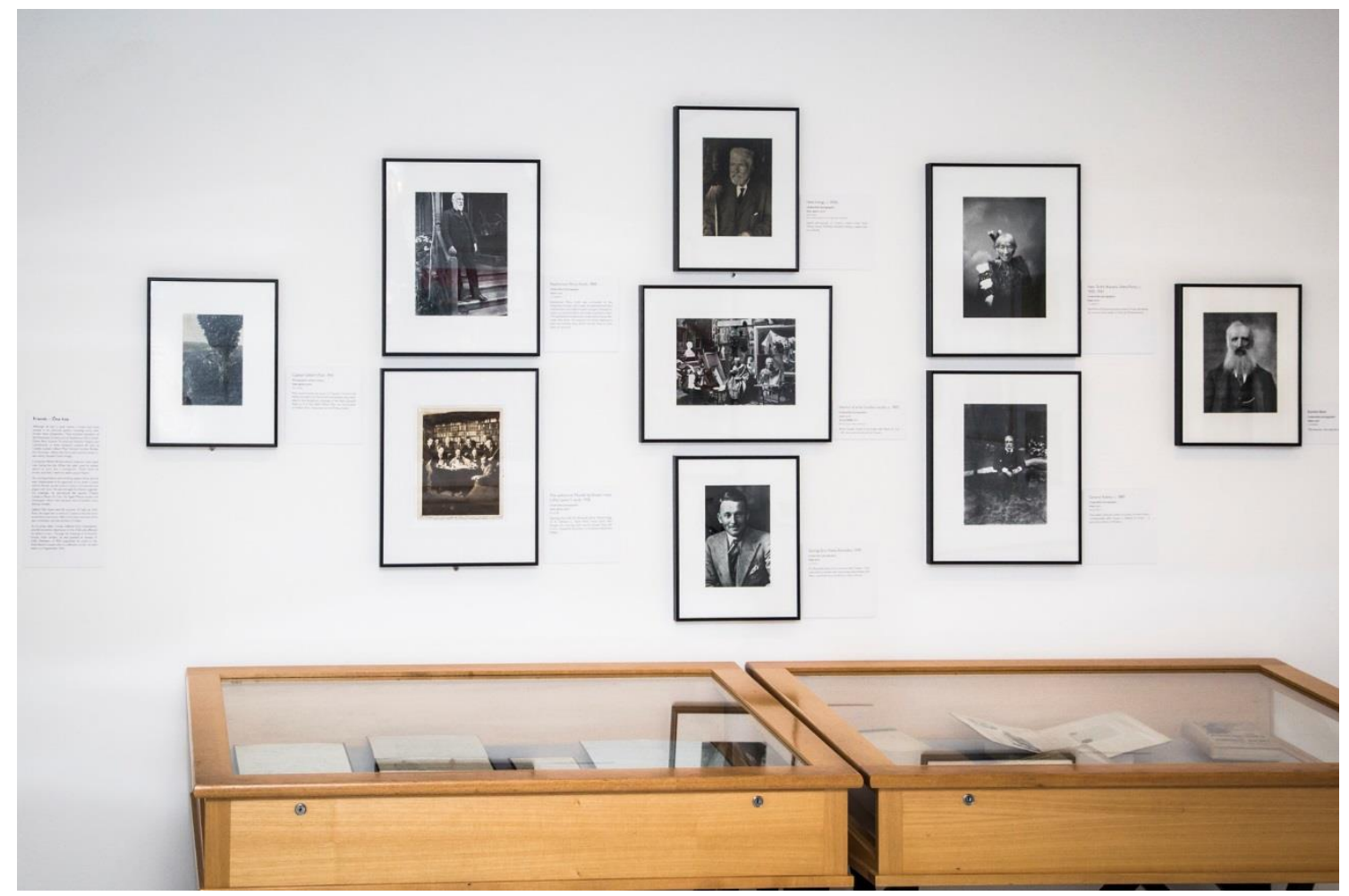

Figure 2. "Friends—Ōna hoa" wall of Borderland. Imaging Services, Alexander Turnbull Library 
For me, the most striking aspect of this section of the exhibition was the salon-style arrangement of black-and-white photographs of many of Cowan's colleagues or friends. They included scholars, artists and writers such as Pat Lawlor, Eric Ramsden, Hare Hongi, Percy Smith and Charles Goldie, and also some of his informants, including the Gate Pā veteran Heni Pore, who wrote to Cowan after being encouraged by their mutual friend Gilbert Mair; and the Pākehā-Māori, Kimble Bent.

Cowan was fascinated by Pākehā-Māori-people of European descent who adopted a Māori way of life. I dedicated a case to Kimble Bent, the American soldier who deserted and went to live with Ngāti Ruanui during the Taranaki war. This case represented not only Cowan's writing about Pākehā-Māori, but also the enduring nature of some of Cowan's stories. In just the last few years, the Kimble Bent story has been retold as a radio serial, as well as in graphic novel form in Kimble Bent: Malcontent, by Chris Grosz. I suggested in this section of the exhibition that, in a way, Cowan was a Pākehā-Māori himself. In a radio interview, composer Alfred Hill said: "Jimmy was more of a Māori than a white man. New Zealand had too few of that kind of man."

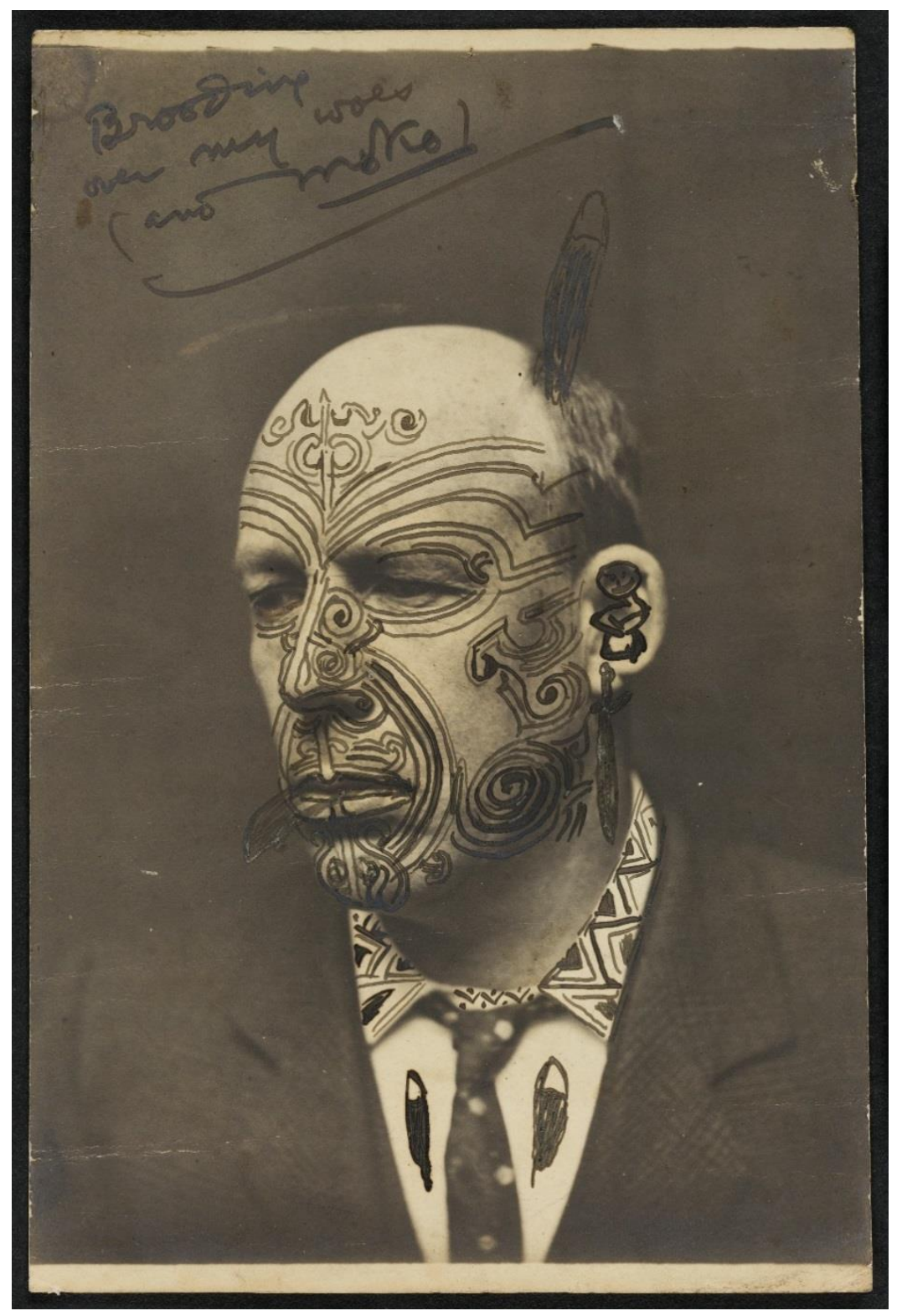

Figure 3. James Cowan with a moko drawn in pen. PAColl-10171. ATL 
This idea of Cowan as a twentieth-century Pākehā-Māori is suggested in this photograph of James Cowan with a moko drawn in pen, which I discovered only about six weeks before the exhibition opened. It had not been described on our catalogue, so had not shown up in any earlier searches of our unpublished collections database. The photograph turned up in the file prints collection in one of our storerooms. Our assistant curator for the Photographic Archive was looking for an image of Cowan's family that was stored next to it, and found it. I was quite taken aback when I saw it, and at first I was not sure whether I could use it in the exhibition, as it would be difficult to contextualise. But after thinking it over, I decided to put it in without any context, and allow people to reflect on what it might mean. The inscription on the item, in Cowan's hand says, "Brooding over my woes (and moko)." Because of this inscription I believe it may have been acquired with the first lot of Cowan papers in 1949 , as many photographs and maps were separated out from that collection, according to the format-driven model of that time.

The Library is moving away from the practices illustrated by the case of this photograph, whereby large multi-format collections were often split up. Sometimes, as in this case, their provenance was lost when they were arranged in subject format in the file prints collection. Planning is under way to implement a modern archival-standards based system which will allow us to keep various format items from the same collection in the same group on our system, intellectually, while providing the best possible physical care and storage based on their physical requirements.

"Ōrākau" was the exhibition's third theme. When conceptualising the themes for the exhibition, I felt a responsibility to strongly acknowledge Örākau for three reasons. Firstly, it was the place where Cowan grew up, and had a huge influence on him. Secondly, the battle is representative of Cowan's research and writing on the New Zealand Wars. Finally, the exhibition coincided with the 150th anniversary of the battle of Örākau. As we acknowledge New Zealand's involvement in World War One with the centenary commemorations that began last year, I wanted to remind people about the wars that happened on our own whenua. There was an emphasis in the public programmes on the kaupapa of Ōākau, which allowed more of this story to be told, from different perspectives.

I also wanted to acknowledge the significance of the place of Ōrākau before the war, represented by the two Joseph Merrett paintings, Two Ladies of Orakau 1840s or Early 1850s, and View from Orakau of Maunga Tatari [sic] with Natives in the Foreground Digging. ${ }^{11}$ These works illustrate the prosperity of the tangata whenua before the war, and what was lost when the land was confiscated. The paintings evoked the comment made by the veteran of the Waikato War who said to Cowan, at the time of the fiftieth Jubilee event, "the Pakeha want bygones to be bygones, but will they give me back my potato ground?" 12

When I wrote about Ōrākau in the exhibition, there were two labels, one which gave a synopsis of the battle, and one which was titled "Ipukarea," which to me encapsulates the emotional attachment to place. In the online Māori dictionary the term is described thus:

Ipukarea (verb) ancestral home, homeland, native land, inherited land-significant water or geographical feature of a tribe's homeland relating to the tribe's identity and the source of their livelihood. Describes a body of water within a vessel, a place that represents the history and emotional attachment of the tribe, a place central to the identity of the people where they can go to be rejuvenated, a place that represents the hopes and aspirations of the people, the lifegiving waters from which they drink. It is also the place associated with significant battles of the tribe and where the bones of their ancestors lie. ${ }^{13}$ 
Cowan's later writing about the Waikato War demonstrates his empathy with the plight of the mana whenua. An example of this can be seen in his draft (c. 1939) for the Waikato chapter of the centennial publication Settlers and Pioneers:

Waikato's story began in a series of errors of judgement - to put it mildly-and developed into a tragedy, the ruin of a people ... the revenge of the so-called rebellion in Waikato was wholesale dispossession and eviction.... It is idle to say that pakeha and Maori are one people, while thousands of Maoris are without sufficient of their own ancestral land on which to make a living. ${ }^{14}$

Chris Hilliard drew on this manuscript material to show that Cowan's version of the Waikato chapter in Settlers and Pioneers was removed from the publication by the centennial committee, and was rewritten to eliminate this criticism. ${ }^{15}$

The fourth section of the exhibition, "Film-Ngā Kiriata," dealt with Cowan's involvement with films. It included references to his early engagements with the French filmmaker Gaston Méliès in 1912, as a cultural advisor and scenario writer, and also featured his work with Rudall Hayward on the films Rewi's Last Stand and The Te Kooti Trail. The new papers included a letter from Rudall Hayward inviting Cowan to act as a historical advisor for Rewi's Last Stand. He also writes that it was Cowan's work which inspired him to make films based on the New Zealand Wars: "I am an earnest reader of all your works, in fact I owe it to your admirable 'Adventures of Kimble Bent' (read at Wanganui college some years ago) for the ambition to some day reproduce on screen the stirring episodes of Maori wars." 16

This section also acknowledged Cowan's story, A Bush Court-Martial, as having inspired the film Utu. As the director of the film, Geoff Murphy, said in an interview on the Flicks website: "The idea came from a book by James Cowan called Tales of the Maori Bush. One of the stories was a detailed account of a bush trial which formed the basis of the final scene in Utu. It was a powerful story, just begging to be made into a film." 17 We included in the exhibition a recording of $A$ Bush Court-Martial read by my colleague Paul Diamond, which is now available online. ${ }^{18}$

The final section dealt with my whānau connections to Cowan, and highlighted some recent finds in the latest Cowan papers. The first case was called "Rāpaki," and centred on handwritten notes that Cowan took while interviewing my great-grandfather, Teone Taare Tikao, at Rāpaki in the 1920s. ${ }^{19}$ Cowan had also drawn a little sketch of the Rāpaki maunga, Te Poho o Tamatea, on these notes. Accompanying the notes in the exhibition were whannau photographs that fitted with the ambience of the manuscript notes, including one of children standing on the main beach at Rappaki, with the mountain that Cowan had drawn in the background. Before I started working on the collection, my father had told me about a waiata in the book Maori Folk-tales of the Port Hills, for which I wrote a new tune, and recorded on my last solo album. Visitors to the gallery could listen to this song on a tablet mounted on the wall in the gallery. It was there partly to demonstrate how Cowan's work is still influencing our cultural life today, much as the Kimble Bent story keeps being retold.

The other case relating to my whānau was called "My family connections-Hononga whānau," which included other items and stories relating to other tīpuna. It included a clipping of a biography of John Tikao Love, a.k.a. Piuraki. ${ }^{20}$ In this article, published in Enzed Junior in 1940, called "The Story of a Maori Sailor: And the One-Sided Land Bargain at Akaroa," Cowan had written some annotations, including "Maori land swindles," which again reflects his empathy with Māori, particularly over what Cowan describes as the "iniquitous terms" of the Kemp purchase of $1848 .{ }^{21}$ It is interesting that he wrote about such a political topic in a mainstream publication, particularly one aimed at children.

This section also included a mōteatea written by "Tikao of the South Island," which was a lament for Toa Rangatira, who drowned near Rangitoto (D'Urville Island) in the 
Marlborough Sounds. At the time, I believed the Tikao that Cowan refers to is my great-greatgrandfather Tamati Tikao, also known as Pukurau. He and his brother Piuraki and other members of our whānau were taken captive by Ngāti Toa in the 1830s raids on Kaiapoi and Banks Peninsula. When Pukurau was released, he lived with Reverend Charles Reay in Nelson and became a lay reader for the Anglican Church. The discovery of this waiata tangi, probably written for a descendant of Ngāti Toa, complicated my understanding of the relationship between the two iwi-particularly given that it was likely to have been composed in the late 1830 s or early 1840s. On a personal level, at least, there must have been some close relationships formed between the enemy tribes. Further research into this waiata casts doubt whether on my ancestor did actually write this lament, but he may still have had some association with it. ${ }^{22}$

Another waiata tangi in this section of Borderland sheds light on other relationships, this time between Māori and Pākehā leaders in the early twentieth century, and reflects on links and differences between Cowan's published and unpublished material. It is a waiata tangi for the Premier, Richard Seddon. James Cowan wrote articles covering Seddon's funeral in 1906 and in one he described the various Māori groups at the funeral, with details such as who were there, the iwi they represented, and what they said and sang. In the exhibition, I focused on Cowan's record of the small Ngāi Tahu contingent. The published component was called "A Ngai Tahu dirge," where he describes the group and includes an English translation of the lament sung by the rangatira:

A Ngai Tahu Dirge

Now came the chiefs of the Greenstone Land-only two or three of them, but the big half-caste rangatira Timoti Whiua (better known as George Robinson), of Little River, Canterbury, made up in size for his people's sparsity of numbers. He is a man of almost gigantic stature, a one-time celebrated wrestler and athlete, and he chanted his dirge with a force and intensity that thrilled his hearers. Prefacing his waiata with a short "poroporoaki" to the dead Premier, he apostrophised the vanished one in poetically figurative terms as the sweet-singing bird of the dawning day, the bright star of the morning, the great one of the earth. ${ }^{23}$

In Cowan's unpublished papers there was a Māori-language version of this waiata tangi, demonstrating the importance of looking at both his published and unpublished papers. There is value in the published article, which gives context in terms of what Cowan wrote for a mainstream contemporary audience to inform them about this significant event. However, the unpublished papers reveal even more treasure, particularly useful for those of us interested in whānau, hapu and iwi cultural revival. This speaks to the symbiotic relationship between items in the unpublished collections and Cowan's published works.

I found this a particularly moving waiata, and as a part of the public programme for Borderland, I composed a new tune for it and performed it. If Cowan had not documented the waiata, and if it had not been saved in these unpublished papers, it would have been impossible to revive this waiata.

\section{Connecting with community}

A bonus of the research phase of the exhibition curation was finding members of Cowan's family, and the Qualtrough family (descending from Cowan's mother's family). Whānau members were great supporters of the exhibition, attending the opening, symposium and many of the associated events. As a result of whānau members visiting the exhibition we also received new information and material. In fact, a further significant new collection of Cowan family papers has recently been acquired by the library, as a direct result of the Borderland exhibition. $^{24}$ 
We also connected with other communities such as the mana whenua in Wellington representing Taranaki Whānui ki Te Ūpoko o Te Ika, who offered tikanga support and conducted opening and closing ceremonies. The local Wellington-based rōpū from Tainui also had representatives who attended the opening and other associated events, and helped host the Ngāti Maniapoto kuia Rovina Maniapoto. Their involvement was valuable to honour the kaupapa of Ōrākau within the exhibition. Members of my whānau attended the opening and supported me in the development of the exhibition.

During the exhibition we had several visits from kura kaupapa and other Māorispecific groups who were very interested in Ōrākau and the other Māori themes.

\section{Related events}

As well as the one-day symposium, a range of talks made up the public programme. The talks were able to fill out some of the themes in the exhibition, particularly the theme of Orākau. The Ngāti Maniapoto kuia Rovina Maniapoto gave an impassioned kōrero focusing on the history that led to the battle of Ōrākau. Her talk explored the earlier Māori history including the battle of Hingakākā, which explained the alliances and why various iwi participated in Örākau. Vincent O'Malley spoke about the historiography of Ōrākau, (see his article in this special issue), and Te Kenehi Teira from Heritage New Zealand/Pouhere Taonga spoke about research surrounding the registration of Waikato War sites.

Other speakers included Roger Blackley (see his article in this issue), Melissa Cross who spoke about Cowan's friendship with Alfred Hill, and Chris Grosz who spoke about his research for Kimble Bent: Malcontent. My colleagues Dr Michael Brown and Keith Thorsen and I conducted a shared session, "Lyrical Legacy," speaking about and performing sea shanties, waiata and poetry associated with Cowan. ${ }^{25}$

I found it both challenging and hugely rewarding to curate Borderland. It was also fascinating to work on the James Cowan papers and get to know more about Cowan in the process. It enabled the Library to highlight the latest purchase, and has encouraged further scholarship relating to James Cowan, helping to make the National Library's aims to "collect, connect and co-create" come to life.

\section{He mihi}

Ngā mihi nunui ki a rātou kua mene atu ki te pō, nā ā rātou mahi, à rātou tuhinga kua whakarangatira i tō tâtou ahurea $\bar{a}-$ motu nei. He mihi hoki ki a tātou te hunga ora, nā koutou i āwhina mai ki tēnei kaupapa, tēnā koutou, tēnā koutou, tēnā tātou katoa. 
${ }^{1}$ These were purchased at auction from Art + Object's rare book auction on 11 July 2012. The library's reference number for this acquisition is A2012-116.

${ }^{2}$ The library's reference number for this second accession is A2012-146.

${ }^{3}$ Definition for the "principle of provenance" from the ICA terminology database: http://www.ciscra.org/mat/termdb/term/275

${ }^{4}$ MS-Papers-0039. Alexander Turnbull Library. This is the reference for the manuscript part of the collection acquired in 1949. There are other references for non-manuscript material.

${ }^{55}$ Defined in the ICA archival terminology database as "Document or paper trail showing the succession of offices or persons having seizure, custody, control, transfer, analysis, and disposition of physical and electronic evidence": http://www.ciscra.org/mat/termdb/term/95

${ }^{6}$ Ngā Ūopko Tukutuku Māori Subject Headings thesaurus at :http://mshupoko.natlib.govt.nz/mshupoko/index.htm

${ }^{7}$ MS-Papers-11310-161. Alexander Turnbull Library (ATL).

${ }^{8}$ My great-grandfather is known to our whānau as Teone Taare Tikao, but often he was known as Hone Taare Tikao to the public. Hone and Teone are both transliterations for John. See his biography at http://www.teara.govt.nz/en/biographies/2t43/tikao-hone-taare

${ }^{9}$ MS-Papers-0039-07C. Letter from Eileen Cowan to Eric Ramsden, dated 6 March 1944. ATL.

${ }^{10}$ ID 23845, Alfred Hill (interviewed by John Mansfield Thomson), Ngā Taonga Sound \& Vision.

${ }^{11}$ A-255-021 [Two ladies of Orakau 1840s or early 1850s], and E-216-f-007 [The Hobson album]. View from Orakau of Maunga tatari with natives in the foreground digging. They dig while sitting in preference to standing [ca 1843], both by Joseph Merrett (1815-1854), ATL.

${ }^{12}$ MS-Papers-0039-54D. ATL.

${ }^{13}$ Definition for 'ipukarea' from http://www.maoridictionary.co.nz

${ }^{14}$ MS-Papers-0039-54D. ATL.

${ }^{15}$ Chris Hilliard, "James Cowan and the Frontiers of New Zealand History," New Zealand Journal of History 31, no 2 (1997): 219-33.

${ }^{16}$ MS-Papers-11310-120. Letter written to James Cowan from Rudall Hayward, date 13 December (1923?), ATL.

${ }^{17} \mathrm{http} / / /$ www.flicks.co.nz/blog/amazing-interviews/interview-utu-redux-director-geoff-murphy/

${ }_{18}$ James Cowan, A Bush Court-Martial, read by Paul Diamond. National Library of New Zealand. https://www.youtube.com/watch?v=1WPZd3HJrkg

${ }^{19}$ MS-Papers-11310-94. ATL.

${ }^{20}$ The uncle of Teone Taare Tikao.

${ }^{21}$ MS-Papers-11310-42. The Story of a Māori Sailor: And the One-Sided Land Bargain at Akaroa. Enzed Junior, November 23, 1940. ATL.

${ }^{22}$ See upcoming issue of Turnbull Library Record (vol. 47, 2015) for an article I have written which analyses this waiata. The article is called "The Taonga of Others."

${ }^{23}$ MS-Papers-11310-33. Clipping relating to a lament chanted by Timoti Whiua, Teoti Rapitini of Wairewa, Little River, Canterbury at the tangihanga of the Premier, Richard Seddon at Parliament House, June 21, 1906. ATL.

${ }^{24}$ This new collection of Cowan family papers has the ATL reference number of MS-Group-2378. At the time of writing, the collection is still being processed and therefore not yet available for research.

${ }^{25}$ See article in this special issue by Michael Brown based on his contribution to this session, and also a blog post he wrote: http://notunlikeatrumpet.wordpress.com/2014/05/03/lifting-the-tardy-anchor/ 